\title{
Controle de Constitucionalidade de Leis Municipais
}

\author{
Renata Pimenta Nunes
}

\section{RESUMO}

Trata-se da questão da constitucionalidade das leis que são criadas dentro da esfera municipal e sua forma de controle. Se o que está sendo criado é constitucional ou não, isto é, se o conteúdo dessas leis obedece aos princípios consagrados pela Constituição Federal, relativos aos direitos e garantias fundamentais tendo em vista o interesse social. E qual a forma de fiscalização e adequação dessas leis através dos dispositivos constitucionais.

Conseqüentemente é um tema que a cada dia ganha mais atualidade e importância para o ordenamento jurídico, pois, após a Constituição de 1988, mercê da legitimação ativa de várias pessoas e entidades para a propositura de ação direta de inconstitucionalidade, e em função da conscientização popular passou-se a questionar, como nunca, as administrações municipais, seus legisladores, suas Câmaras Municipais, enfim, a própria legislação municipal.

Palavras-Chaves: Fiscalização, Constitucionalidade, Municipal, Difuso, Concentrado, Hermenêutica, Leis.

\section{ABSTRACT \\ Constitutionality Control and the Municipal Laws}

It deals with the issue of constitutionality of laws that are created inside the municipal sphere and its forms of control. If what is being created is constitutional or not, that is, if the contents of such laws obey the principles established by the Federal Constitution in relation to the fundamental rights and guarantees according to the social interest. And which form of surveillance and adequacy of such laws through constitutional tools.

Consequently, it is a topic that becomes more and more current and important for the legal order because after the Constitution of 1988 due to the Active legitimation of various persons and entities for the propose of the direct action of unconstitutionality, and because of the popular consciousness, the municipal administration, its legislators, its municipal chamber, the municipal legislation itself began to be questioned.

Keywords: Surveillance, Constitutionality, Municipal, Diffuse, Concentrated, Hermeneutics, Laws

\section{Notas Introdutórias}

A origem da fiscalização da constitucionalidade é longínqua e a diversidade de órgãos e sistemas para tanto criados, bastante grande. Há países que adotaram o meio jurisdicional, quer atribuindo tal função do Poder Judiciário comum (caso dos EUA), quer criando órgãos específicos (Tribunais Constitucionais) para exercer a função, mas inserindo-os também no Poder Judiciário (Alemanha). 
A idéia de controle de constitucionalidade brasileira, inspirada no modelo americano, encontra-se, intimamente, atrelada à supremacia da Constituição sobre todo ordenamento jurídico e, também, à rigidez constitucional e proteção dos direitos fundamentais.

Trata-se, então, da questão da constitucionalidade das leis que são criadas dentro da esfera municipal e sua forma de controle. Se o que está sendo criado é constitucional ou não, isto é, se o conteúdo dessas leis obedece aos princípios consagrados pela Constituição Federal, relativos aos direitos e garantias fundamentais tendo em vista interesse social. E qual a forma de fiscalização e adequação dessas leis através dos dispositivos constitucionais.

É relevante, também, destacar a importância do Município dentro da organização político-administrativa, decorrência do fato de a Carta Magna tê-lo consagrado como entidade federativa indispensável ao nosso sistema federativo e garantindo-lhe plena autonomia.

Ressalta, neste aspecto, Paulo Bonavides:

não conhecemos uma única forma de união federativa contemporânea onde o princípio da autonomia municipal tenha alcançado grau de caracterização política e jurídica tão alto e expressivo quanto aquele que consta da definição constitucional do novo modelo implantado no País com a Carta de $1988 .{ }^{1}$

A autonomia proporciona à Administração Municipal capacidade de gerir os seus próprios interesses, destacando-se entre eles, a competência para criar leis dentro de sua área de atuação, que influenciam muitas vezes todo o cenário nacional. Não se pode esquecer que, existem, no Brasil, municípios de grande relevância no âmbito federal, cuja edição de leis inconstitucionais implica a geração de inúmeras demandas judiciais, com sérios prejuízos para as partes e para a segurança jurídica.

A importância do tema é ressaltada por Raul Machado Horta, dissertando acerca da fiscalização constitucional, ensina que:

O controle de constitucionalidade das leis é o corolário lógico da supremacia constitucional, seu instrumento necessário, o requisito para que a superioridade constitucional não se transforme em preceito moralmente platônico e a Constituição em simples programa político, moralmente obrigatório, um repositório de bons conselhos, para uso esporádico ou intermitente do legislador, que lhe pode vibrar, impunemente, golpes que a retalham e desfiguram. ${ }^{2}$

\footnotetext{
${ }^{1}$ BONAVIDES, Paulo. Curso de direito constitucional. $9^{\mathrm{a}}$ ed. São Paulo: Malheiros, 2000, p. 314.

${ }^{2}$ HORTA, Raul Machado. Direito Constitucional, 2003, p. 132.
} 
Neste sentido, a jurisdição constitucional, muitas vezes tão esquecida pelos aplicadores do direito, deve ser exercida sempre que houver uma norma em desconformidade com a Lei Maior, pois, é sua função primordial, o controle de constitucionalidade.

Entretanto, o controle de constitucionalidade de leis municipais tem gerado muita divergência não só no âmbito da doutrina, mas do mesmo modo, no campo da jurisprudência.

Essa discussão gira em torno da forma de controle concentrado, ou seja, do controle realizado pelo Supremo Tribunal Federal.

Por conseguinte, apesar de a temática ser bem divergente, é pacífico afirmar que o controle de constitucionalidade das leis municipais deve existir. O que se discute é, necessariamente, como ele deve ser realizado. E a partir daí surgem inúmeros questionamentos, tais como: Quais os métodos que melhor vão adequar-se ao sistema constitucional brasileiro? Deve ou não haver o meio concentrado no controle de constitucionalidade municipal? Com o surgimento da lei $\mathrm{n}^{\circ} .9 .882$, de 3 de dezembro de 1999, é possível o ajuizamento de uma argüição de descumprimento de preceito fundamental, visando declarar a inconstitucionalidade de uma lei municipal face a Constituição Federal? Entre tantas outras questões.

\section{Supremacia constitucional: hierarquia normativa}

A Constituição traduz os principais valores da sociedade a serem preservados. Representa os princípios basilares do Estado. A Constituição apresenta-se como uma idéia ou conceito síntese aonde a Nação deposita suas aspirações e desejos da Nação.

Sendo assim, a norma constitucional, pela sua natureza superior, justifica bem o nome que se lhe dá de lei das leis. Ela contém os princípios fundamentais da ordem social, política, econômica e jurídica. Esses princípios, essencialmente dogmáticos, orientam e disciplinam a conduta dos governantes e dos particulares. A eles se subordinam necessariamente as leis e os atos de governo.

Dessa forma, as normas não são da mesma classe, não estão alinhadas num mesmo plano. Ao contrário, estão dispostas sob uma ordem hierárquica, ou seja, constituem uma estrutura piramidal. E, no topo desta estrutura, localizam-se as normas constitucionais.

\section{Hermenêutica constitucional}


A Constituição Federal protege e regulamenta vários bens jurídicos, como também, serve de parâmetro de averiguação constitucional de diversas leis. Os conflitos de normas da própria Carta Magna e das demais leis não são raros, cabendo, pois, aos intérpretes encontrar o melhor sentido da norma jurídica através da conjugação de seu texto com as características históricas, políticas, ideológicas da época, e do confronto com a realidade sociopolíticoeconômica da sociedade.

Segundo Maximiliano “interpretar uma expressão do Direito não é simplesmente tornar claro o respectivo dizer, abstratamente falando; é, sobretudo, revelar o sentido apropriado para a vida real, e conducente a uma decisão reta" ${ }^{3}$.

De tal modo que a interpretação é antes de qualquer coisa uma atividade criadora. Em toda a interpretação existe, portanto uma criação de direito.

\title{
3.1. A interpretação conforme a Constituição
}

A interpretação conforme a Constituição é um princípio constitucional, sendo denominada na Alemanha de Verfassungskonforme Auslegung. Pode-se dizer que graças a sua flexibilidade, ela "permite uma renúncia ao formalismo jurídico e às interpretações convencionais em nome da idéia de justiça material e da segurança, elementos tão necessários para um estado democrático de direito". ${ }^{4}$

Segundo esse princípio, nas palavras de Konrad Hesse:

\begin{abstract}
Uma lei não deve ser declarada nula quando pode ser interpretada em consonância com a Constituição. Essa consonância existe não só então, quando a lei, sem a consideração de pontos de vista jurídicosconstitucionais, admite uma interpretação que é compatível com a Constituição. No quadro da interpretação conforme a Constituição, normas constitucionais são, portanto, não só normas de exame, mas também normas materiais para a determinação do conteúdo das leis ordinárias ${ }^{5}$.
\end{abstract}

Assim, as modernas técnicas (em especial a técnica da interpretação conforme a Constituição) objetivam conservar a norma no ordenamento jurídico tendo como escopo o princípio da economia e como fundamento a busca de compatibilizar a norma tida como inconstitucional com a Carta Magna. "Parte-se da idéia de que na maioria dos casos essa

\footnotetext{
${ }^{3}$ MAXIMILIANO, Carlos. Hermenêutica e aplicação do direito. $9^{\mathrm{a}}$ ed. Rio de Janeiro: Forense, 1981, p. 09-10.

${ }^{4}$ BASTOS, Celso Ribeiro. As modernas formas de interpretação constitucional. Jus Navegandi. Teresina, ano 3 , n. 27, dez. 1998. Disponível em: <http://jus2.uol.com.br/doutrina/texto.asp?id=89>. Acesso em: 05 jun. 2010.

${ }^{5}$ HESSE, Konrad. Elementos do direito constitucional da república federal da Alemanha. $20^{a}$ ed. alemã. Porto Alegre: Sérgio Antônio Fabris Editor, 1998, p. 71.
} 
inconstitucionalidade da norma, vai dar lugar a um vazio legislativo, que produzirá sérios danos" 6 .

Uma das soluções apontadas para se proceder à interpretação conforme a Constituição e não retirar a lei do ordenamento jurídico é a declaração de nulidade parcial sem redução de texto, isto é, a norma passa a viger de acordo com a interpretação dada pela Corte Suprema sendo excluídas todas as outras interpretações existentes. De modo mais claro, seria a atribuição de um novo sentido, que redunda em uma nova norma, sem alteração do texto, em virtude da norma ser sempre o resultado da interpretação do texto.

Além disso, ainda sobre as modernas técnicas de interpretação, faz-se necessário ressaltar a contribuição de Peter Häberle para hermenêutica, que numa visão inovadora entende que:

\begin{abstract}
a teoria da interpretação constitucional esteve muito vinculada a um modelo de interpretação de uma sociedade fechada. Ela reduz, ainda, seu âmbito de investigação, na medida em que se concentra, primariamente, na interpretação constitucional dos juízes e nos procedimentos formalizados ${ }^{7}$.
\end{abstract}

O referido jurista, nesta nova teria, procura demonstrar que até o presente momento a interpretação constitucional esteve restrita aos intérpretes jurídicos vinculados às corporações e às partes formais do processo. Por isto, ele acredita que o processo de interpretação constitucional deva possuir um caráter aberto e pluralista, onde a ampliação do círculo de intérpretes tenha como conseqüência a integração da realidade no processo interpretativo.

Daí a importância da hermenêutica na construção do Direito, sendo que, ela deve ser realizada por uma sociedade aberta, onde todos os envolvidos sejam intérpretes, posto que, ela representa o primeiro pilar que perpassa o controle de constitucionalidade.

\title{
4. Sistema brasileiro de controle de constitucionalidade
}

Existem quanto ao momento de realização dois tipos de controle: repressivo e preventivo. $\mathrm{O}$ controle repressivo busca retirar do ordenamento jurídico qualquer norma

\footnotetext{
${ }^{6}$ BASTOS, Celso Ribeiro. As modernas formas de interpretação constitucional. Jus Navegandi. Teresina, ano 3, n. 27, dez. 1998. Disponível em: <http://jus2.uol.com.br/doutrina/texto.asp?id=89>. Acesso em: 17 jan. 2007.

${ }^{7}$ HÄBERLE, Peter. Tradução por MENDES, Gilmar Ferreira. Hermenêutica constitucional - a sociedade aberta dos intérpretes da constituição: contribuição para interpretação pluralista e procedimental da constituição. Porto Alegre: Metrópole Indústria Gráfica, 1997, p. 12.
} 
editada em desrespeito à Constituição. Já o preventivo pretende impedir que alguma norma viciada pela inconstitucionalidade ingresse no ordenamento jurídico.

O controle preventivo é realizado antes da aprovação da lei, incide sobre o projeto de lei, podendo ser exercido tanto pelo poder legislativo como pelo executivo. O legislativo executa esse controle através das Comissões de Constituição e Justiça existentes em toda Casa Legislativa - art. 58, CF e o executivo mediante o veto do Presidente da República ao projeto de lei aprovado pelo Congresso Nacional - art. 66, § $1^{\circ}, \mathrm{CF}$.

O controle repressivo com relação ao órgão controlador pode ser: político, judiciário ou misto.

O Brasil adotou, em regra, o sistema jurisdicional, em que o controle de constitucionalidade é exercido de forma repressiva, ou seja, após a elaboração da lei ou ato normativo, pelos integrantes do poder Judiciário.

O controle jurisdicional, na visão de José Afonso, "é a faculdade de que as constituições outorgam ao Poder Judiciário de declarar a inconstitucionalidade de lei e de outros atos do Poder Público que contrariem, formal ou materialmente, preceitos ou princípios constitucionais" 8 .

A Constituição Federal, excepcionalmente, admite em duas hipóteses que o controle repressivo seja realizado pelo poder legislativo. A primeira hipótese refere-se ao decreto legislativo do Congresso Nacional que susta os atos normativos do poder executivo que exorbitem o poder regulamentar (art. 84, inc. IV, $2^{\text {a }}$ parte $\mathrm{CF}$ ) ou dos limites da delegação legislativa (art. $68, \S 2^{\circ}, \mathrm{CF}$ ), conforme o disposto no art. 49, V, CF.

A segunda hipótese são as medidas provisórias rejeitadas pelo Congresso Nacional por apresentarem vício de constitucionalidade, em virtude de não atenderem aos pressupostos constitucionais de relevância e urgência, de acordo com art. $62, \S 5^{\circ}, \mathrm{CF}$.

Esse controle repressivo pode ser feito por ação ou omissão, e ainda, pelos critérios difuso e concentrado.

4.1. Formas de inconstitucionalidade: ação ou omissão

A inconstitucionalidade é a incompatibilidade entre a uma norma e a Constituição Federal. Existem duas formas de inconstitucionalidade: por ação e por omissão.

\footnotetext{
${ }^{8}$ SILVA, José Afonso da. Curso de direito constitucional positivo. 24. ed. Malheiros, 2005, p. 49.
} 
A inconstitucionalidade por ação é a produção de atos legislativos ou normativos que contrariem dispositivos constitucionais, podendo ser por motivos formais ou materiais.

Já a inconstitucionalidade por omissão é a não elaboração de atos legislativos ou normativos que inviabilizem o exercício de preceitos constitucionais.

Duas ações foram introduzidas pela Constituição de 1988 para solucionar a inércia legislativa ou administrativa: a ação de inconstitucionalidade por omissão (art. 103, § $2^{\circ}$ ) e o mandado de injunção (art. $5^{\circ}$, LXXI).

\subsection{Controle difuso}

No controle difuso, também chamado de em concreto, indireto da constitucionalidade, via de defesa, de exceção ou aberto, o objeto da ação é a "apreciação de uma situação jurídica concreta, em que a questão da invalidade da norma é levantada a título de incidente perante qualquer juiz ou Tribunal" 9 .

A inconstitucionalidade pode ser argüida via incidental ou de defesa por qualquer das partes. Pelo autor pode ser argüida em sede de mandado de segurança, habeas corpus ou qualquer outra ação. Pelo réu, em sua defesa judicial.

A decisão dessa ação produz efeitos inter partes, e somente vincula e produz coisa julgada para as partes da relação processual, não se estendendo a terceiros, contra quem continua produzindo seus efeitos normais.

Entretanto, caso a ação indireta chegue ao Supremo Tribunal Federal, em sede de recurso extraordinário, para que a decisão faça coisa julgada não só entre as partes, há necessidade de comunicação ao Senado Federal, afim de que ele providencie a suspensão da executoriedade da lei declarada inconstitucional (art. 52, X, CF).

\subsection{Controle concentrado}

O controle concentrado, também conhecido por direto de constitucionalidade, em abstrato, via principal ou de ação, consiste na verificação da conformidade ou não das normas jurídicas com a Constituição, independentemente da existência de um caso em concreto.

\footnotetext{
${ }^{9}$ FLORES, Patrícia Teixeira de Rezende. Aspectos processuais da ação direta de inconstitucionalidade de lei municipal. São Paulo: Editora Revista dos Tribunais, 2002, p. 70.
} 
O objeto da ação é a própria declaração da inconstitucionalidade ou constitucionalidade do ato legislativo ou normativo, devendo essa ação ser proposta diretamente perante o Supremo Tribunal Federal.

Os legitimados para proporem ação direta são somente os mencionados nos art. 103 da Constituição Federal, não podendo esse rol ser ampliado.

A sua decisão tem efeito erga omnes, ou seja, vale para todos, produzindo coisa julgada mesmo para as pessoas e órgãos que não participaram da ação.

Trata-se de ação de competência originária do Supremo Tribunal Federal, cujo procedimento está estabelecido na Lei n. ${ }^{\circ}$ 9868/99. Se a inconstitucionalidade for de lei estadual ou municipal perante a Constituição Estadual, a competência originária será dos Tribunais de Justiça de cada Estado (art. 125, § $2^{\circ}$ ).

A Constituição de 1988 reservou à ação direta de inconstitucionalidade os art. 102, I, a, primeira parte, e 103 .

Contudo, deve-se mencionar também, que a $E C n^{\circ} 45 / 2004$, dando nova redação ao art. $102, \S 2^{\circ}$, concluiu por dar eficácia erga omnes e efeito vinculante para as decisões definitivas de mérito, proferidas pelo Supremo Tribunal Federal, nas ações diretas de inconstitucionalidade e nas ações declaratórias de constitucionalidade.

Isso implica que a lei declarada inconstitucional ou constitucional tem eficácia contra todos e vincula os demais órgãos do Poder Judiciário e à administração direta e indireta, nas esferas federal, estadual e municipal.

\section{O município na Constituição de 1988.}

O Estado brasileiro é denominado República Federativa do Brasil. Nesta assertiva está abrangida, além da forma de governo - República, também a forma de Estado - Federação.

Assim, a Constituição de 1988 consagra o sistema federativo através do seu artigo $1^{\circ}$, verbis: “A República Federativa do Brasil, formada pela união indissolúvel dos Estados e Municípios e do Distrito Federal, constitui-se em Estado Democrático de Direito", e no mesmo sentido, o art. 18 disciplina que "A organização político-administrativa da República Federativa do Brasil compreende a União, os Estados, o Distrito Federal e os Municípios, todos autônomos, nos termos desta Constituição".

\subsection{Autonomia municipal}


O vocábulo autonomia deriva do grego autonomia (autos - si mesmo e nomos - lei), e significa a "faculdade que possui determinada pessoa ou instituição, em traçar as normas de sua conduta, sem que sinta imposições restritivas de ordem estranha" ${ }^{10}$. Em outros termos, é a faculdade atribuída a alguém, de dirigir-se, através de leis próprias.

A Constituição de 1988 consagrou em seus arts. 18 e 29 a autonomia municipal, cujas características são: a tríplice capacidade de auto-organização e legislação própria, autogoverno e auto-administração.

Dessa forma, de acordo com Alexandre de Morais:

o município auto-organiza-se através de sua Lei Orgânica Municipal e, posteriormente, por meio da edição de leis municipais; autogoverna-se mediante a eleição direta de seu prefeito, Vice-prefeito e vereadores, sem qualquer ingerência dos Governos Federal e Estadual; e, finalmente, auto-administra-se, no exercício de suas competências administrativas, tributárias e legislativas, diretamente conferidas pela Constituição Federal ${ }^{11}$.

Autonomia municipal é corroborada, ainda, pelo disposto no art. 35 da Constituição Federal, que proíbe a intervenção do Estado nos Municípios, salvo ocorrendo alguma das hipóteses autorizadoras.

Neste contexto, uma observação se faz necessária, soberania e autonomia são coisas distintas, sendo que aquela é exercida em face de outro Estado, igualmente soberano, enquanto que esta é exercida dentro e entre as pessoas políticas de um Estado soberano.

\subsection{Autonomia política, administrativa e financeira}

Com relação ao aspecto político da autonomia pode-se destacar a capacidade de estruturação dos Poderes Executivo e Legislativo, bem como o relacionamento entre eles. Então, a municipalidade tem a capacidade de organizar e constituir seu próprio governo.

Já no aspecto administrativo o Município possui independência e autonomia para administrar e prestar serviços de interesse local. Existem, dessa maneira, matérias locais distintas dos assuntos nacionais ou, mesmo, regionais.

A organização dos serviços públicos locais encontra-se voltada para aqueles que dizem respeito à vida urbana, em particular aos transportes, instrução primária, saúde, água, saneamento, pronto-socorro, sinalização das vias públicas, logradouros, assistência social e

\footnotetext{
${ }^{10}$ SILVA, De Plácido e. Vocabulário jurídico. 3. ed., v. I, São Paulo: Forense, 1993, p. 251.

${ }^{11}$ MORAES, Alexandre. Direito Constitucional. 13 ${ }^{\text {a }}$ ed. São Paulo: Atlas, 2003, p. 274.
} 
muitos outros que satisfaçam às necessidades coletivas e ao bem-estar geral da municipalidade.

A autonomia financeira configura-se por meio do poder atribuído ao Município para arrecadar os seus tributos e aplicar as suas rendas, atendendo aos limites da Lei Orçamentária.

Reza o art. 30, inciso III, da Carta Magna que compete ao Município "instituir e arrecadar os tributos de sua competência, bem como aplicar suas rendas, sem prejuízo da obrigatoriedade de prestar constas e publicar balancetes nos prazos fixados em lei”.

A arrecadação tributária municipal foi ampliada, tendo, agora os municípios competência para instituir, nos termos do art. 156 da CF, os seguintes impostos: propriedade predial e territorial urbana; transmissão inter vivos, a qualquer título, por ato oneroso, de bens imóveis, por natureza ou acessão física, e de direitos reais sobre imóveis, exceto os de garantia, bem como cessão de direitos a sua aquisição; serviços de qualquer natureza, não compreendidos 155, II, da Constituição Federal, definidos em lei complementar.

Além disso, prevê o texto constitucional a repartição de receitas tributárias (arts. 158 e 159), bem como a aplicação do fundo de participação dos municípios em determinados percentuais, que lhes permitam o considerável aumento de seu poder econômico e financeiro.

Destarte, a autonomia financeira é assegurada, no atual texto constitucional, pela instituição e arrecadação de tributos, bem como pelo recebimento de repasses das verbas referentes a tributos arrecadados por outros entes federativos - União e Estados-membros.

De tal modo que o Município é livre para gerir e aplicar o produto de sua arrecadação nos projetos que melhor atendam ao interesse público.

\section{Controle de constitucionalidade de leis municipais em face à Constituição Federal}

A possibilidade de controle da constitucionalidade de lei municipal perante a Constituição Federal é uma questão extremamente peculiar, em decorrência das discussões por inúmeras vezes suscitadas na doutrina e na jurisprudência, conforme análise abaixo.

\subsection{Controle difuso}

No que diz respeito ao controle difuso é necessário fazer a diferenciação entre o controle incidental exercido ante a Carta Estadual e a Carta Federal.

Com relação ao controle difuso realizado em face da Constituição Federal, as decisões dos tribunais inferiores poderão ser analisadas novamente pelo Supremo Tribunal Federal, em 
grau de recurso extraordinário - art. 102, inc. III, $a$ e $c$, da CF: "julgar, mediante recurso extraordinário, as causas decididas em única ou última instância, quando da decisão recorrida: a) contrariar dispositivo desta Constituição; c) julgar válida lei ou ato normativo de governo local contestado em face desta Constituição".

Todavia, no caso de infração à Constituição Estadual por ato normativo municipal, as decisões prolatadas por tribunais inferiores somente serão revistas pelo Tribunal de Justiça, não cabendo recurso ao Supremo, salvo se o dispositivo impugnado reproduzir norma constitucional federal de observância compulsória para os Estados-membros.

Caso não ocorra a exceção acima, prevalecerá a Súmula 280 do Supremo Tribunal Federal, que dispõe não caber recurso extraordinário por ofensa ao direito local.

\subsection{Controle concentrado}

A Constituição de 1998 silencia sobre o controle de constitucionalidade, em tese, de leis e atos normativos municipais perante a Constituição Federal. Preceitua o art. 102, inc. I, $a$, da CF:

Compete ao Supremo Tribunal Federal, precipuamente, a guarda da Constituição, cabendo-lhe: I - processar e julgar, originalmente: a) ação direta de inconstitucionalidade de lei ou ato normativo federal ou estadual e a ação declaratória de constitucionalidade de lei ou ato normativo federal.

O Min. Cunha Peixoto, em seu voto na Representação 92.169-SP, reconheceu a omissão da Constituição Federal ao não mencionar o controle de constitucionalidade dos atos municipais, admitindo que pudesse ser preenchida essa lacuna. Foram essas as suas palavras:

\footnotetext{
Assim, o silêncio da Constituição relativamente às leis municipais obriga o STF a enfrentar o problema, preenchendo a lacuna pela interpretação integradora da plenitude do sistema. E este impõe que as normas constitucionais sejam controladas pelo mais alto Poder Judiciário do País, sejam elas federais, estaduais ou municipais ${ }^{12}$.
}

Nesse voto, o Ministro reconheceu ser falho o controle de constitucionalidade via ação direta, diante da ausência manifesta de referência a atos normativos municipais, tendo em vista a condição de guardião da Lei Suprema confiada à Corte Máxima, o que justificaria o preenchimento da lacuna deixada pelo legislador constituinte.

\footnotetext{
${ }^{12}$ STF, RE 9.169-SP, RTJ 103, p. 1.102-3.
} 
Para Sérgio Ferraz, que não obstante o Supremo Tribunal Federal afirmar univocamente que não lhe compete julgar ação direta, quando em contraste ato normativo municipal e a Constituição Federal, ele não se conforma com esse entendimento.

Sustenta o referido autor que:

o ato municipal pode produzir efeitos práticos muito danosos e "socialmente perturbadores, ao arrepio da Constituição". Também submetê-lo apenas ao controle difuso significa despi-lo de eficácia erga omnes. Logo em seguida, conclui que, assim como nos Estados Unidos o controle de constitucionalidade nasceu no caso Marbury versus Madison, sem qualquer previsão legal ou constitucional, no Brasil poderia ocorrer o mesmo. "Ora, identicamente, poderia assim construir doutrina o Supremo, dando, destarte, resposta positiva a um verdadeiro anseio da coletividade jurídica e da sociedade como um todo" 13 .

Entretanto, o Supremo Tribunal Federal professa posicionamento segundo o qual essa lacuna do art. 102, I, a da Lei Maior, foi deixada propositalmente pelo legislador constituinte que quis excluir do controle abstrato as leis e os atos normativos municipais, deixando que a fiscalização de sua legitimidade em face da Constituição Federal seja desempenhada, tão somente, por meio do método difuso ${ }^{14}$.

Nesse propósito, tem-se a ADI 2172 - Min. Celso de Mello:

Controle abstrato de constitucionalidade. Ação direta. Ilegitimidade ativa de prefeito municipal. Impossibilidade jurídica de fiscalização normativa abstrata de lei municipal contestada em face da constituição federal. Ação direta de que não se conhece. - Os Prefeitos Municipais e os Municípios - mesmo que se trate de impugnação in abstracto de leis estaduais ou federais contestadas em face da Constituição da República - não dispõem de legitimidade ativa para o ajuizamento da ação direta de inconstitucionalidade perante o Supremo Tribunal Federal, eis que são de direito estrito as hipóteses previstas no rol taxativo constante do art. 103 da Carta Política. Precedentes. - O

\footnotetext{
${ }^{13}$ FERRAZ, Sérgio. A declaração de inconstitucionalidade no Supremo Tribunal federal. Ajuris 61, p. 239. Já para Regina Nery Ferrari, parece o art. 102, I, $a$ da CF, "admitir a argüição de inconstitucionalidade de lei municipal frente à Constituição Federal só por via de defesa ou exceção o que pode ser considerado como uma falha do Legislador Constituinte, pois determinou até mesmo o controle genérico frente à Constituição Estadual [...] Não é possível, assim, que, dentro da sistemática brasileira, se negue ao Procurador-Geral da República o direito de acionar o Supremo Tribunal Federal para, diretamente, invalidar uma lei que traga tal defeito, apenas porque é da órbita municipal e a ela não se referiu a Constituição" (FERRARI, Regina Macedo Nery. Elementos de direito municipal. São Paulo: Editora Revista dos Tribunais, 1993, p. 125 e 130).

${ }^{14} \mathrm{O}$ Supremo Tribunal Federal não admite o controle concentrado de leis municipais, mas somente o controle pela via incidental, STF, ADI 1.803-0-SP - Eis o teor do acórdão - "Ação direta de inconstitucionalidade de lei municipal proposta, perante este Supremo Tribunal Federal, por Mesa de Câmara Municipal. - Dois são os óbices para o conhecimento da presente ação direta de inconstitucionalidade: o de que a Mesa de Câmara Municipal não tem legitimidade ativa para propor ação dessa natureza por não estar arrolada no "caput" do artigo 103 da Constituição Federal, e o de que há impossibilidade jurídica do pedido, uma vez que, em face do disposto no artigo 102, I, "a", da Carta Magna, só cabe ação direta de inconstitucionalidade perante esta Corte quando se tratar de lei ou ato normativo federal ou estadual, e não de lei ou ato normativo municipal. Ação direta de inconstitucionalidade não conhecida" (STF, ADI 1.803-0-SP, Rel. Min. Moreira Alves, DJU, 24 abr. 1998, p. 4).
} 
sistema constitucional brasileiro não permite o controle normativo abstrato de leis municipais, quando contestadas em face da Constituição Federal. A fiscalização de constitucionalidade das leis e atos municipais, nos casos em que estes venham a ser questionados em face da Carta da República, somente se legitima em sede de controle incidental (método difuso). Desse modo, inexiste, no ordenamento positivo brasileiro, a ação direta de inconstitucionalidade de lei municipal, quando impugnada in abstracto em face da Constituição Federal ${ }^{15}$ (grifo nosso).

Na mesma linha de raciocínio, Luiz Alberto David Araújo leciona que:

logo de início, verificamos que o ato municipal não foi incluído no campo material da ação direta de inconstitucionalidade. Essa falta de previsão constitucional faz com que o ato municipal que fira a Constituição Federal fique, em princípio, sem controle direto, devendo ser discutido apenas pela via de exceção. Entende-se que essa omissão da Constituição foi proposital, expressando, portanto, um posicionamento jurídico do constituinte. Bem por isso, costuma-se designar esse fenômeno como silêncio eloqüente [...] Entretanto, a matéria pode ser discutida, respeitadas outras exigências, pela argüição de descumprimento de preceito fundamental - Lei n. 9.882/99, art. $1^{\mathrm{o}}, \mathrm{I}^{16}$.

Por sua vez, com base no art. $125, \S 2^{\circ}$, da Constituição Federal, os Estados-membros acharam que estavam autorizados a disciplinarem a ação direta de inconstitucionalidade tanto diante da Carta Estadual, quanto na Carta Federal, atribuindo ao Tribunal de Justiça local essa competência, em função de os Municípios serem entidades infra-estaduais, o que autorizaria os Estados a prover sobre o sistema de defesa de ambas as esferas constitucionais: estadual e federal ${ }^{17}$.

Em virtude disso, algumas Constituições Estaduais instituíram em seu texto o controle de constitucionalidade de leis e atos normativos municipais em face da Constituição Federal, aumentando a competência dos Tribunais de Justiça.

Isso aconteceu, por exemplo, no Estado de São Paulo, havendo o legislador inserido no texto constitucional estadual a possibilidade de o Tribunal de Justiça alegar a inconstitucionalidade de lei municipal perante a Constituição Federal.

Por conseguinte, a Constituição do Estado de São Paulo teve seu artigo 74, inc. XI, impugnado através da ADI 347-6/600, sendo que, o Supremo Tribunal Federal suspendeu a eficácia do artigo acima no tocante à parte que instituía o controle em abstrato da lei municipal frente à Constituição Federal. Eis o teor do acórdão:

\footnotetext{
${ }^{15}$ STF, ADI 2.172 MC, Rel. Min. Celso de Melo, DJU, 16 mar. 2000, p. 4.

${ }^{16}$ ARAUJO, Luiz Alberto David e outro. Curso de direito constitucional, São Paulo: Saraiva, 2006, p. 41.

${ }^{17} \mathrm{O}$ art. 125, § $2^{\circ}$, da Constituição Federal estabelece que: "Cabe aos Estados a instituição de representação de inconstitucionalidade de leis ou atos normativos estaduais ou municipais em face da Constituição Estadual, vedada a atribuição da legitimação para agir a um único órgão".
} 
Ação direta de inconstitucionalidade. Pedido de suspensão liminar da expressão "federal" contida no inciso XI do artigo 74 da Constituição do Estado de São Paulo, promulgada em 5 de outubro de 1989, o qual atribui competência ao tribunal de justiça para processar e julgar originariamente "a representação de inconstitucionalidade de lei ou ato normativo municipal em face da constituição federal". Ocorrência, no caso, de relevância da fundamentação jurídica do pedido, bem como de conveniência da suspensão liminar da eficácia da expressão impugnada. Liminar deferida para suspender a eficácia da expressão "federal" contida no inciso XI do artigo 74 da Constituição do Estado de São Paulo, promulgada em 5 de outubro de $1989^{18}$.

Ainda com relação à Constituição do Estado de São Paulo, tem-se a ADI 347/SP do STF:

Ação direta de inconstitucionalidade. Constituição do Estado de São Paulo. Art. 74, XI. Controle de constitucionalidade, pelo Tribunal de Justiça, de lei ou ato normativo municipal em face da constituição federal. Procedência. É pacífica a jurisprudência do Supremo Tribunal Federal, antes e depois de 1988, no sentido de que não cabe a Tribunais de Justiça estaduais exercer o controle de constitucionalidade de leis e demais atos normativos municipais em face da Constituição federal. Precedentes. Inconstitucionalidade do art. 74, XI, da Constituição do Estado de São Paulo. Pedido julgado procedente $^{19}$.

Então, o Estado, no exercício da competência que lhe foi dada pelo constituinte originário, o realiza na condição de poder decorrente, pois isso mesmo limitado, motivo pelo qual, ao introduzir sistema de proteção a sua Constituição, não poderá desobedecer aos princípios consagrados na Carta Magna, devendo agir, por conseguinte, apenas no campo da autonomia que lhe é atribuída pela Constituição Federal.

Em conformidade com o posicionamento do Supremo, Sílvio Roberto Mello de Moraes afirma:

\begin{abstract}
$\mathrm{Na}$ ausência da previsão legal, entendemos que o controle jurisdicional da constitucionalidade de leis ou atos normativos municipais em contraste com a Constituição Federal só poderá se dar de forma difusa e concreta e não por via de ação direta. A par disso, algumas constituições estaduais previram esta forma de controle, atribuindo aos seus respectivos Tribunais de Justiça, a competência para julgá-los, o que, ao nosso ver, extrapola o conteúdo da norma
\end{abstract}

\footnotetext{
18 STF, ADI-MC 347-SP, Rel. Min. Moreira Alves, DJU, 26 out. 1990, p. 25. No mesmo sentido, o STF posicionou-se a respeito da Constituição do Rio Grande do Sul, eis o teor do acórdão: “Ação direta de inconstitucionalidade. Constituição do Estado do Rio Grande do Sul. Preceito que defere competência ao Tribunal de Justiça para processar e julgar ação direta de lei ou ato normativo municipal questionado perante a Constituição Federal. Suspensão cautelar deferida”.

${ }^{19}$ STF, ADI 347-SP, Rel. Min. Joaquim Barbosa, DJU, 20 out. 2006, p. 48.
} 
prevista no art. $125, \S 2^{\circ}$ da Lei Maior, bem como colide com o novo perfil do Supremo Tribunal Federal de guardião da Constituição da República ${ }^{20}$.

Ao se aceitar que os Tribunais dos Estados pudessem consolidar posicionamento sobre uma norma perante a Constituição Federal, com eficácia ergam omnes, estar-se-ia constituindo vinculação da Corte Suprema a decisão decorrente de órgão hierarquicamente inferior.

A este respeito, tem-se o voto do Ministro Celso de Melo na medida cautelar da ação direta de inconstitucionalidade 409-3:

\begin{abstract}
Atente-se à circunstância de que uma decisão eventualmente proferida pelo Tribunal de Justiça, ao apreciar, em sede jurisdicional concentrada, a legitimidade de lei ou ato normativo municipal perante a Constituição Federal, nos termos preconizados pela Carta estadual, geraria, essencialmente pelos efeitos subordinantes e excludentes que pertinem à própria natureza da jurisdição constitucional concentrada, situação jurídica de todo incompatível com a posição institucional do Supremo Tribunal Federal, que se submeteria, inobstante sua condição de órgão maior incumbido do controle dos atos estatais em face da própria Carta Federal, à imperatividade dos pronunciamentos emanados de um órgão judiciário inferior ${ }^{21}$.
\end{abstract}

No entanto, é importante ainda ressaltar que o silêncio do legislador constituinte é discutível, pois mesmo admitindo que grande parte desses litígios ocasione também a inconstitucionalidade no campo estadual, sujeitos, conforme o art. $125, \S 2^{\circ}$, de serem apreciados pelo Tribunal de Justiça dos entes estaduais, esses conflitos podem suceder do confronto entre a lei e a Constituição Federal sem desacatar à Constituição Estadual, e nesses casos deverão esperar que alguém venha expor a incompatibilidade no decorrer de um processo singular, o que se pode ocasionar, ainda, a existência de decisões conflitantes que operem umas no sentido da constitucionalidade, outras no da inconstitucionalidade do mesmo preceito normativo, o que, substancialmente, fere o princípio constitucional da segurança das relações jurídicas.

Todavia, atualmente, apesar de ainda existirem debates doutrinários, em sede jurisprudencial o tema encontra-se solidificado, culminando na afirmativa de que não há controle de constitucionalidade de leis municipais em face da Constituição Federal e que as Constituições estaduais não podem regular tal matéria.

\footnotetext{
${ }^{20}$ MOARES, Sílvio Roberto Mello. Apontamentos sobre o controle jurisdicional de leis e atos normativos estaduais e municipais na constituição do estado do rio de janeiro. Caderno de Direito Constitucional e Ciências Políticas, n. 2, jan. - mar., 1993, p. 231.

${ }^{21}$ STF, ADI 409-3 MC, DJU, 15 mar. 1991.
} 
Ademais, se o constituinte federal concedesse ao Supremo Tribunal Federal competência para a análise da constitucionalidade das leis municipais, seguramente a quantidade de Ministros seria insuficiente, em decorrência do elevado número de Municípios existentes no país, o que geraria um caos na Corte Suprema.

Neste aspecto, o controle de constitucionalidade difuso ganhou um reforço, e foi criada a súmula vinculante por meio da Emenda Constitucional n. ${ }^{\circ}$ 45/2004 que deu novo vigor ao sistema brasileiro, e que viabilizou que o Supremo edite súmulas de caráter vinculante todas as vezes que a questão constitucional tenha sido objeto de reiteradas decisões sobre norma acerca da qual haja controvérsia atual entre órgãos judiciários ou entre esses e a administração pública, uma controvérsia de tal monta que acarrete grave insegurança jurídica e relevante multiplicação de processos sobre questão idêntica.

Busca-se, desse modo, resgatar a efetividade do devido processo legal por meio de um instituto que irá estabelecer o entendimento da Suprema Corte Federal brasileira sobre matérias constitucionais de direito, tornando a exegese fixada pelo Pretório Excelso de observância obrigatória por todos os órgãos e entes derivados dos Poderes Constituídos Judiciário e Executivo, os quais se limitarão à análise de aspectos fáticos, tão-somente, como forma de se reduzir o lapso temporal referente ao trâmite procedimental na Justiça e na Administração Pública e de se garantir a segurança jurídica na Nação.

Em suma, a Carta Magna de 1988 conferiu ao Supremo Tribunal Federal a competência para julgar a ação direta de inconstitucionalidade de lei ou ato normativo federal ou estadual em contraste com Constituição Federal, mediante controle concentrado. E igualmente, deixou que os entes estaduais estabelecessem o mesmo mecanismo de fiscalização da constitucionalidade de lei ou ato normativo estadual ou municipal ante a Constituição Estadual.

O que deixa claro que o silêncio do legislador constituinte em não disciplinar o controle concentrado municipal configurou-se na "expressa vontade de restringir o controle de constitucionalidade abstrato ao modelo explicitamente definido no Texto Magno" 22.

\section{Argüição de descumprimento de preceito fundamental (ADPF)}

\footnotetext{
22 MENDES, Gilmar Ferreira. Controle de constitucionalidade: aspectos jurídicos e políticos. São Paulo: Saraiva, 1990, p. 319.
} 
A argüição de descumprimento de preceito fundamental está prevista no artigo 102, $\S 1^{\circ}$ da Constituição Federal de 1988: “A argüição de descumprimento de preceito fundamental, decorrente desta Constituição, será apreciada pelo Supremo Tribunal Federal, na forma da lei”, contudo, a sua regulamentação só foi definida posteriormente através da Lei 9.882 de 1999. Mais precisamente, depois de passados onze anos da promulgação da Constituição Federal de 1988.

O termo argüiçãa significa exame, pergunta ou questão e foi utilizado no art. $102, \S^{\circ}$ da CF como o meio ou instrumento colocado à disposição para o exercício do controle abstrato de constitucionalidade, para alegar uma violação a um preceito fundamental da Constituição.

A argüição, quanto ao momento da lesão ao preceito fundamental, pode ser classificada em: argüição preventiva e argüição repressiva.

Essa classificação tem por base o disposto no artigo $1^{\circ}$, caput, da Lei 9882/99: "A argüição prevista no $\S 1^{\circ}$ do art. 102 da CF será proposta perante o STF, e terá por objeto evitar ou reparar lesão a preceito fundamental, resultante de ato do Poder Público”.

$\mathrm{O}$ artigo transcrito acima demonstra que é possível ajuizar uma argüição preventiva para evitar condutas do Poder Público que possam colocar em perigo os preceitos constitucionais fundamentais e, de outro lado, a argüição repressiva para fazer cessar condutas do Poder Público lesiva aos preceitos fundamentais.

Em consonância com Alexandre de Morais, caberá, preventivamente, argüição de descumprimento de preceito fundamental perante o Supremo Tribunal Federal com o objetivo:

de se evitar lesões a princípios, direitos e garantias fundamentais previstos na Constituição Federal, ou, repressivamente, para reparálas, quando causadas pela conduta comissiva ou omissiva de qualquer dos poderes públicos. [...] O Supremo Tribunal Federal poderá, de forma rápida, geral e obrigatória - em face da possibilidade de liminar e da existência de efeitos erga omnes e vinculantes - evitar ou fazer cessar condutas do poder público que estejam colocando em risco os preceitos fundamentais da República, e em especial, a dignidade da pessoa humana (CF, art. $1 .^{\circ}$, III) e os direitos e garantias fundamentais. 
A argüição também pode ser classificada em autônoma (direta ou principal) e incidental (paralela ou incidente processual de constitucionalidade) quanto ao controle de constitucionalidade que realiza ${ }^{23}$.

O termo descumprimento significa deixar de realizar, não satisfazer, ou seja, não cumprir um preceito constitucional fundamental, isto é, descumprimento é espécie do gênero inconstitucionalidade.

O descumprimento possui a mesma classificação dada pelos doutrinadores à inconstitucionalidade, tais como: inconstitucionalidade formal e material; inconstitucionalidade total ou parcial; inconstitucionalidade por ação e por omissão; etc.

O descumprimento formal é quando ocorre vício de competência do órgão que realiza o ato do Poder Público ou quando não foi seguido o procedimento previsto na Lei Fundamental. E material quando se constata alguma violação dos preceitos constitucionais fundamentais.

O descumprimento é total quando todo o ato é viciado e é parcial quando vicia somente parte dele.

O descumprimento é por ação ou omissão, quando o fato de praticar um ato ou deixar de praticá-lo implica numa violação à Constituição.

O termo preceito pode ser traduzido tanto, genericamente, em regra ou dispositivo, como para designar princípio, expresso ou tácito, do texto constitucional.

Contudo, não são todos os princípios constitucionais que servem de base para a admissibilidade de uma argüição de descumprimento, mas apenas os princípios fundamentais e por fundamental entende-se aqueles preceitos, regras ou princípios que constituem a essência da Constituição, ou seja, que fazem parte de seu alicerce.

André Ramos Tavares dispõe quanto aos preceitos fundamentais que:

\footnotetext{
${ }^{23}$ Esclarecendo a diferença entre a argüição autônoma e incidental, tem-se a ADPF-QO 3 / CE: “[...] 1. A Constituição Federal de 5.10.1988, no parágrafo único do art. 102, estabeleceu: a argüição de descumprimento de preceito fundamental decorrente desta Constituição será apreciada pelo Supremo Tribunal Federal, na forma da lei. Esse texto foi reproduzido como $\S 1$ o do mesmo artigo, por força da Emenda Constitucional $\mathrm{n}^{\mathrm{o}} 3$, de 17.03.1993. 2. A Lei $\mathrm{n}^{\mathrm{o}}$ 9.882, de 03.12.1999, cumprindo a norma constitucional, dispôs sobre o processo e julgamento da argüição de descumprimento de preceito fundamental. No art. 1o estatuiu: "Art. $1 \mathrm{o}$ - A argüição prevista no § 1 o do art. 102 da Constituição Federal será proposta perante o Supremo Tribunal Federal, e terá por objeto evitar ou reparar lesão a preceito fundamental, resultante de ato do Poder Público." Trata-se, nesse caso, de Argüição autônoma, com caráter de verdadeira Ação, na qual se pode impugnar ato de qualquer dos Poderes Públicos, no âmbito federal, estadual ou municipal, desde que para evitar ou reparar lesão a preceito fundamental da Constituição. 3. Outra hipótese é regulada no parágrafo único do mesmo art. 1 o da Lei ${ }^{\circ}$ 9.882/99, "in verbis": Parágrafo único. "Caberá também argüição de descumprimento de preceito fundamental: I - quando for relevante o fundamento da controvérsia constitucional sobre lei ou ato normativo federal, estadual ou municipal, incluídos os anteriores à Constituição" (ADPF-QO 3 / CE, Rel. Min. Sydney Sanches, DJU, 27 fev. 2004, p. 20).
} 
é preciso também afastar a possibilidade de que 'preceito fundamental' seja toda e qualquer norma contida na Lei Fundamental. Se, teoricamente, essa construção é admissível, o mesmo não ocorre quanto ao vigente sistema constitucional. É que, se assim fosse, então tornar-se-ia repetitiva a parte final do $\S 1^{\circ}$ do art. 102 quando se refere a 'preceito fundamental decorrente desta Constituição'. Ora, se 'fundamental' fosse sinônimo de 'constitucional', a Constituição simplesmente teria sido redundante ${ }^{24}$.

Como não há um rol enumerando os preceitos fundamentais, isso viabiliza que a jurisprudência tenha maior flexibilidade ao analisar os princípios e com maior facilidade se adapte às mudanças da sociedade, aplicando a hermenêutica constitucional evolutiva, tanto no sentido de considerar um princípio como fundamental, bem como para deixá-lo de aplicá-lo no decorrer da evolução histórica do Direito.

Entretanto, apesar de não haver um rol específico, pode-se afirmar que se constituem preceitos fundamentais: a soberania, a cidadania, a dignidade da pessoa humana, os valores sociais do trabalho e da livre iniciativa, o pluralismo político, a forma federativa de Estado, o voto direto, secreto, universal e periódico e os direitos e garantias individuais (art. $1^{\circ}$ e $60, \S 4^{\circ}$ da CF).

\subsection{O caráter subsidiário da argüição de descumprimento}

A ADPF possui caráter subsidiário, pois a utilização dessa via de controle concentrado tratará somente de questões residuais, de situações em que não exista outra maneira eficaz de evitar a lesividade (art. $4^{\circ}, \S 1^{\circ}$ da Lei 9.882).

Contudo, de acordo com a opinião de Lênio Streck, não se torna

desarrazoado afirmar que a exigência que lei regulamentadora faz do
esgotamento das vias judiciárias pode tornar a ADPF inócua e
desnecessária, uma vez que existe o recurso extraordinário como meio
de levar as discussões acerca da violação da Constituição até a
instância máxima que é o STF. [...] torna-se imperativo que o
Supremo Tribunal faça uma interpretação conforme a Constituição
(verfassungskonforme Auslegung), permitindo que, em determinadas
circunstâncias, não se torne exigível o esgotamento das vias
judiciárias. Pensar o contrário é esvaziar esse importante instituto,
além de estabelecer uma leitura metafísica do mesmo, obstaculizando
o aparecer da singularidade.[...] Assim, em face desse processo
hermenêutico, torna-se razoável afirmar, a partir da redação da Lei
regulamentadora, que a argüição de descumprimento de preceito

${ }^{24}$ TAVARES, André Ramos. Tratado da argüição de preceito fundamental: (Lei 9.868/99 e Lei 9.882/99). São Paulo: Saraiva, 2001, p. 121-122. 
fundamental (ADPF) é, efetivamente, um remédio supletivo para os casos em que não caiba ação direta de inconstitucionalidade ${ }^{25}$.

Dessa maneira, ainda no pensamento do jurista acima, poderão agora ser discutidos por meio de ADPF atos normativos (regulamentos, resoluções, por exemplo), que anteriormente, não eram suscetíveis de apreciação pelo Supremo através de ação direta de inconstitucionalidade. $\mathrm{O}$ mesmo raciocínio vale para as resoluções expedidas pelas Agências Reguladoras, bem como para o controle de leis municipais em face da Constituição Federal ${ }^{26}$. 7.1.1. Argüição autônoma (direta ou principal)

A Lei 9882, de 3 de dezembro de 1999 disciplinou o processo e julgamento da argüição de descumprimento de preceito fundamental, dando-lhe contornos absolutamente semelhantes às ações diretas de inconstitucionalidade, assim, na argüição autônoma, da mesma forma que ocorre na ação direta genérica, procura defender, através de um processo objetivo, os preceitos da Constituição Federal, ou seja, tem por objetivo "evitar ou reparar lesão a preceito fundamental, resultante de ato do poder público" (art. 1º, caput da Lei 9.882/99) .

Assim, a ADPF direta ou autônoma é uma típica ação de controle concentrado e principal de constitucionalidade com o objetivo de defesa de preceitos fundamentais ameaçados ou lesados por qualquer ato do poder público.

Por conseguinte, a Lei 9.882 trouxe para o controle concentrado leis municipais, estaduais e federais, ampliando este controle, que antes se limitava apenas aos atos estaduais e federais.

\subsection{Competência e legitimidade}

\footnotetext{
${ }^{25}$ STRECK, Lênio Luiz. Jurisdição constitucional e hermenêutica: uma nova crítica do direito. $2^{\mathrm{a}}$ ed. Rio de Janeiro: Forense, 2004, p. 814.

${ }^{26}$ No que tange ao caráter subsidiário da ADPF, o Supremo tem-se manifestado da seguinte maneira: Ementa: Direito Constitucional. Argüição de Descumprimento de Preceito Fundamental (Art. 102, § $1^{\circ}$, da Constituição Federal, $1^{\circ}$ e seguintes da Lei ${ }^{\circ}$ 9.882, de 3 de dezembro de 1999). Vencimentos de servidores públicos ativos e proventos de inativos. Gratificações. Vantagens. Cálculo de acréscimos pecuniários. Teto de vencimentos e proventos. Impugnações de decisões monocráticas e colegiadas do Tribunal de Justiça do Ceará, proferidas em reclamações. Alegação de violação aos Arts. 5, LIV e LV, 37, "Caput" e Inciso XIV, 100, § 2º da C.F. de 1988, bem como ao art. 29 da Emenda Constitucional no 19/98. Questão de Ordem. Medida Cautelar. [...] 7. Dispõe, contudo, o § 1o do art. 4o do diploma em questão: "§ 1o - Não será admitida argüição de descumprimento de preceito fundamental quando houver qualquer outro meio eficaz de sanar a lesividade". 8. E ainda há meios judiciais eficazes para se sanar a alegada lesividade das decisões impugnadas. 9. Se, na Corte estadual, não conseguir o Estado do Ceará obter medidas eficazes para tal fim, poderá, em tese, renovar a Argüição de Descumprimento de Preceito Fundamental.[...] 12. Questão de Ordem que o Supremo Tribunal Federal resolve não conhecendo da presente Argüição de Descumprimento de Preceito Fundamental, ficando, em consequiência, prejudicado o pedido de medida liminar. (ADPF-QO 3 / CE, Rel. Min. Sydney Sanches, DJU, 27 fev. 2004, p. 20).
} 
Somente o Supremo Tribunal Federal tem competência para processar e julgar a argüição de descumprimento de preceito fundamental. Trata-se de um sistema concentrado de jurisdição constitucional ${ }^{27}$.

Já os legitimados passivos da ADPF são as autoridades, órgãos ou entidades responsáveis pela prática do ato questionado ou pela omissão impugnada. O Advogado-Geral da União deve desempenhar o mesmo papel exercido no caso de ADIN genérica, ou seja, deve atuar como curador da presunção de constitucionalidade do ato questionado, seja ele normativo ou não. Certo que, em se tratando de omissão do poder público, à semelhança da ADIN por omissão, não cabe a atuação do Advogado Geral da União, salvo em se tratando de omissão parcial.

Com o veto ao inciso II do art. $2^{\circ}$ da Lei $9.882 / 99$, que permitia o ajuizamento da argüição a qualquer pessoa lesada ou ameaçada por ato do Poder Público, sua propositura ficou reservada, exclusivamente, aos co-legitimados para a ação direta de inconstitucionalidade (art. $2^{\circ}$, I, da Lei 9.882/99, c/c art. 103 da CF).

Ao lado disso, foi mantido o $\S 1^{\circ}$ do mesmo artigo, que, trazendo preceito dependente do inciso II mencionado, faculta a qualquer interessado, “mediante representação, solicitar a propositura de argüição de descumprimento de preceito fundamental ao Procurador-Geral da República, que, examinando os fundamentos jurídicos do pedido, decidirá do cabimento do seu ingresso em juízo".

\subsection{O processo e julgamento da ADPF}

O procedimento da argüição, tanto autônoma quanto incidental, inicia-se por petição que satisfaça os requisitos do art. $3^{\circ}$ da Lei 9.882/99:

I - a indicação do preceito fundamental que se considera violado; II - a indicação do ato questionado; III - a prova da violação do preceito fundamental; IV - o pedido, com suas especificações; V - se for o caso, a comprovação da existência de controvérsia judicial relevante sobre a aplicação do preceito fundamental que se considera violado.

\footnotetext{
${ }^{27} \mathrm{O}$ artigo $2^{\circ}$ da Lei 9.882 dispõe que: Podem propor argüição de descumprimento de preceito fundamental: I os legitimados para a ação direta de inconstitucionalidade; II - (VETADO); $§ 1^{\circ}$ Na hipótese do inciso II, facultase ao interessado, mediante representação, solicitar a propositura de argüição de descumprimento de preceito fundamental ao Procurador-Geral da República, que, examinando os fundamentos jurídicos do pedido, decidirá do cabimento do seu ingresso em juízo. $\S 2^{2}$ (VETADO).
} 
O relator em caso de não cabimento da argüição de descumprimento de preceito fundamental, inépcia ou falta dos requisitos legais poderá indeferir liminarmente a petição inicial, sendo que desta decisão caberá agravo.

Em caso de extrema urgência ou perigo de lesão grave, cabe medida liminar na ADPF, que será concedida pelo relator, sob o referendo do plenário.

O objeto da liminar poderá versar sobre pedido de suspensão de andamentos e processos ou dos efeitos das decisões judiciais, ou de qualquer outra medida que tenha relação com a matéria objeto da argüição.

A concessão da liminar implicará, de acordo com o caso em concreto, na antecipação da tutela pleiteada ou em outro provimento que assegure a efetividade do julgamento definitivo.

Ao apreciar a liminar, o relator poderá solicitar informações aos responsáveis pela elaboração do ato, podendo, inclusive, determinar a requisição de informações adicionais, a designação de perícia ou audiência pública para oitiva de especialistas.

Mesmo nas argüições incidentais, não é imprescindível a oitiva das partes que compõem a relação processual originária, mas, se entender necessário, poderá relator ouvi-las ou, ainda, requisitar informações adicionais, designar perito ou comissão de peritos para que emita parecer sobre a questão, ou ainda, fixar data para declarações, em audiência pública, de pessoas com experiência e autoridade na matéria $\left(\operatorname{art.} 6^{\circ}, \S^{\circ}\right)$.

Posteriormente, o Supremo Tribunal Federal deve proceder ao julgamento da argüição, determinando as condições e o modo de exegese do preceito fundamental. A decisão terá efeito vinculante para os demais órgãos do Poder Público, sendo que por dois terços de seus membros, o Supremo pode modular os efeitos da decisão.

7.4. Objeto: os atos ou omissões que descumprem preceitos constitucionais fundamentais

Pela argüição de descumprimento de preceito fundamental são controláveis todos os atos do poder público ofensivos a preceitos constitucionais fundamentais, sejam atos normativos ou não.

O objeto da ADPF abrange: atos normativos; atos não normativos (atos concretos ou individuais do Estado e da Administração Pública, atos e fatos materiais, atos do poder público regidos pelo direito privado, contratos administrativos, e até mesmo atos judiciais); atos anteriores à Constituição. 
Assim, o objeto da ADPF traz uma grande novidade para o ordenamento jurídico, pois sempre se entendeu que os atos normativos anteriores à Constituição "estão fora do controle concentrado (estariam revogados pela Constituição, nunca se admitiu no Brasil a inconstitucionalidade superveniente), bem assim os atos normativos municipais em confronto com a Constituição Federal, cujo controle concentrado, pelo Supremo Tribunal, sempre se entendeu vedado" 28 .

Contudo, é importante ressaltar que somente são objetos da ADPF os atos (normativos ou não) do Poder Público que descumpram preceitos fundamentais da Constituição Federal.

\title{
7.5. Decisão e seus efeitos
}

A exemplo do art. 27 da Lei 9.868/99, também na Lei 9.882/99 foi consagrada hipótese de exceção à regra da nulidade do ato impugnado, mediante a seguinte previsão:

\begin{abstract}
Ao declarar a inconstitucionalidade de lei ou ato normativo, no processo de argüição de descumprimento de preceito fundamental, e tendo em vista razões de segurança jurídica ou de excepcional interesse social, poderá o Supremo Tribunal Federal, por maioria de dois terços de seus membros, restringir os efeitos daquela declaração ou decidir que ela só tenha eficácia a partir de seu trânsito em julgado ou de outro momento que venha a ser fixado (art. 11).
\end{abstract}

Julgada a argüição, as autoridades responsáveis pela prática do ato impugnado serão comunicadas da decisão, que poderá ainda fixar as condições e o modo de aplicação e interpretação do preceito fundamental (art. 10, caput).

Os efeitos da decisão da argüição de descumprimento de preceito fundamental são erga omnes, como característica do controle concentrado, bem como de caráter vinculante.

Os atos objetos da argüição podem ter origem em qualquer um dos poderes da República e a decisão tem efeito vinculante sobre estes, conforme o art. $10, \S 3^{\circ}$ da lei 9.882/99.

Pode o Supremo, ainda, excepcionar a própria regra do efeito "erga omnes" e do efeito declaratório ou "ex tunc" de suas decisões, atribuindo efeitos mais limitados ou constitutivos, ou mesmo "ex nunc", sob o argumento da segurança jurídica e estabilidade das relações.

De qualquer forma, a decisão que julgar procedente ou improcedente o pedido da ADPF é irrecorrível, não podendo ser reformada via ação rescisória (art. 12 da Lei 9.882/99).

\footnotetext{
28 PALU, Oswaldo Luiz. Controle de constitucionalidade: conceitos, sistemas e efeitos. $2^{\text {a }}$ ed. São Paulo: Revista dos Tribunais, 2001, p. 263-264.
} 
7.6. Argüição incidental (paralela ou incidente processual)

$\mathrm{Na}$ argüição incidental existe um processo prévio, submetido a qualquer juízo ou tribunal, abarcando uma controvérsia constitucional relevante, cujo parâmetro de controle seja um preceito constitucional fundamental.

A argüição sob a modalidade incidental ou indireta está contida no parágrafo único do art. 1': "Caberá também argüição de descumprimento de preceito fundamental: I - quando for relevante o fundamento da controvérsia constitucional sobre lei ou ato normativo federal, estadual ou municipal, incluídos os anteriores à Constituição”.

Esse parágrafo revela a natureza subjetiva-objetiva, incidental ou indireta da argüição de descumprimento de preceito fundamental, pressupondo a existência de controvérsia sobre lei ou ato normativo, de todos os órgãos políticos autônomos, bem como dos anteriores à Constituição.

Aplicam-se à ADPF incidental as mesmas regras aplicadas à ADPF autônoma quanto à legitimidade, competência, procedimento, medida liminar, objeto, decisão e seus efeitos, com algumas observações.

A ADPF incidental possibilita o trânsito direto e imediato ao STF de uma questão constitucional relevante, discutida no âmbito de instâncias judiciais ordinárias, que envolva a interpretação e aplicação de um preceito constitucional fundamental.

Trata-se de um controle misto de constitucionalidade, pelo qual se combina as dimensões abstrata e difusa, que permite o traspassamento do controle difuso para o controle concentrado, mediante um processo de generalização dos efeitos jurídicos do julgado original, a partir de um controle abstrato posterior.

Contudo, a transição do controle difuso à via concentrada dependerá, sempre, da comprovação da relevância da controvérsia constitucional, a ser aferida, comumente, perante a presença de efetiva divergência jurisdicional na aplicação do texto impugnado.

Relativamente à argüição incidental Daniel Sarmento sustenta que:

o objetivo do novo instituto é antecipar decisões do Supremo Tribunal Federal sobre controvérsias constitucionais relevantes, que antes só chegariam a seu conhecimento muito depois, após o percurso das tortuosas vias recursais. Evita-se com isso que, neste ínterim, seja criada e alimentada uma situação de incerteza jurídica, congestionado os tribunais, ensejando a possibilidade de decisões discrepantes e permitindo a consolidação no tempo de situações subjetivas que 
possam vir a contrariar a orientação que, depois, o Supremo Tribunal venha adotar em relação a certas questões de índole constitucional ${ }^{29}$.

Destarte, a argüição incidental de descumprimento de preceito fundamental completa o sistema nacional de controle abstrato de constitucionalidade, permitindo ao Supremo Tribunal Federal seu exercício mesmo em relação às normas municipais, o que viabiliza a efetiva garantia de supremacia da Constituição Federal, aliada à rápida e eficaz uniformização de sua interpretação.

Com relação à legitimidade ativa da ação incidental para propositura da ADPF perante o STF, ela encontra-se disciplinada no art. $2^{\circ}$, inciso I, da Lei ${ }^{\circ}$ 9.882/99. Ocorre que o inciso II ("qualquer pessoa lesada ou ameaçada por ato do Poder Público") foi objeto de veto presidencial, conforme explicado acima.

Portanto, apenas podem propor a ADPF os legitimados ativos para a propositura da Ação Direta de Inconstitucionalidade (art. 103, CF). Ao interessado que se considerar ameaçado ou lesionado resta, tão-somente, nos termos do art. $2^{\circ}, \S^{\circ}$, da Lei ${ }^{\circ} 9.882 / 99$, representar ao Procurador-Geral da República, que, examinando os fundamentos jurídicos do pedido, decidirá do cabimento do seu ingresso em juízo.

7.7. O controle direto de constitucionalidade de leis municipais frente à Constituição federal e a argüição de descumprimento de preceito fundamental

Como anteriormente afirmado (4.2), a Constituição de 1998 silencia sobre o controle direto de constitucionalidade, em tese, de leis e atos normativos municipais perante a Constituição Federal. Preceitua o art. 102, inc. I, $a$, da CF:

\footnotetext{
Compete ao Supremo Tribunal Federal, precipuamente, a guarda da Constituição, cabendo-lhe: I - processar e julgar, originalmente: a) ação direta de inconstitucionalidade de lei ou ato normativo federal ou estadual e a ação declaratória de constitucionalidade de lei ou ato normativo federal (grifo nosso).
}

Então a Lei 9882/99 veio suprir a lacuna deixada pelo constituinte no art. 102, inc. I, $a$, da $\mathrm{CF}$, disciplinando, expressamente, a possibilidade de controle de constitucionalidade de lei municipal perante a Constituição.

\footnotetext{
29 SARMENTO, Daniel. Apontamentos sobre a argüição de descumprimento de preceito fundamental: parâmetro de controle e objeto. In: André Ramos Tavares; Walter Claudius Rothenburg (Org.). Argüição de descumprimento de preceito fundamental: análise à luz da Lei n. 9.882/99. São Paulo: Athas, 2001, p. 88.
} 
A esse respeito, Gilmar Mendes, leciona que:

Ao contrário do imaginado por alguns, não será necessário que o STF aprecie as questões constitucionais relativas ao direito de todos os municípios. Nos casos relevantes, bastará que decida uma questãopadrão com força vinculante. Se entendermos, como parece recomendável, que o efeito vinculante abrange também os fundamentos determinantes da decisão, poderemos dizer, com tranqüilidade, que não apenas a lei objeto da declaração de inconstitucionalidade no Município "A" mas toda e qualquer lei municipal de idêntico teor não poderão ser aplicadas. Em outras palavras, se o STF afirmar, em um processo de argüição de descumprimento, que a Lei n. "X", do Município de São Paulo, que prevê a instituição do IPTU progressivo, é inconstitucional, essa decisão terá efeito não apenas em relação a esse texto normativo, mas também em relação aos textos normativos de teor idêntico editados por todos os demais entes comunais ${ }^{30}$.

Em sentido contrário, Alexandre de Moraes afirma que o legislador ordinário utilizouse de manobra para ampliar, irregularmente, as competências constitucionais do Supremo Tribunal Federal, que:

conforme jurisprudência e doutrina pacíficas, somente podem ser fixadas pelo texto magno. Manobra essa eivada de flagrante inconstitucionalidade, pois deveria ser precedida de emenda à Constituição. Note-se que foi criada pela Lei $n .^{\circ} 9.882 / 99$ a possibilidade de um dos co-legitimados argüir ao Supremo Tribunal Federal a inconstitucionalidade de uma lei ou ato normativo, fora das hipóteses cabíveis no controle concentrado, quais sejam - controvérsia constitucional relevante sobre lei ou ato normativo municipal e controvérsia constitucional sobre lei ou ato normativo federal, estadual ou municipal anteriores à Constituição Federal. Em ambas as hipóteses o Supremo Tribunal Federal já havia decidido faltar-lhe competência para essa análise, em sede de ação direta de inconstitucionalidade, por ausência de previsão expressa na Constituição Federal, não sendo admissível que o legislador ordinário, por meio de uma manobra terminológica amplie essa competência sem alterar o art. 102, 1 , a, da $\mathrm{CF}^{31}$.

Contudo, a Corte Suprema ainda está construindo jurisprudência a respeito do tema e no julgado da argüição de descumprimento de preceito fundamental n. ${ }^{\circ} 33$, declarou que:

\footnotetext{
${ }^{30}$ MENDES, Gilmar Ferreira. Direitos fundamentais e controle de constitucionalidade. 3. ed., São Paulo: Saraiva, 2004, p. 370-371. No mesmo sentido, Roberto Mendes Mandelli Junior: "Passam a ser suscetíveis do controle abstrato de constitucionalidade, também, as leis e os atos normativos municipais e os atos normativos das unidades autônomas da federação, anteriores à Constituição, desde que descumpram preceito constitucional fundamental" (MANDELLI JUNIOR, Roberto Mendes. Argüição de descumprimento de preceito fundamental: instrumento de proteção dos direitos fundamentais e da Constituição. São Paulo: Editora Revista dos Tribunais, 2003, p. 134-135). No mesmo aspecto Regina Ferrari: "Agora, o controle abstrato de leis municipais perante as normas constitucionais federais - quando constituam preceitos fundamentais - pode ser realizado pelo Supremo Tribunal Federal" (FERRARI, Regina Maria Macedo Nery. Controle de Constitucionalidade das Leis municipais. 3. ed. São Paulo: Editora Revista dos Tribunais, 2003, p. 187).

${ }^{31}$ MORAES, Alexandre. Direito Constitucional. $13^{\text {a }}$ ed. São Paulo: Atlas, 2003, p. 646.
} 


\begin{abstract}
a argüição de descumprimento poderá ser manejada para solver controvérsias constitucionais sobre a constitucionalidade do direito federal, do direito estadual e também do direito municipal. Pode-se dizer que a argüição de descumprimento vem completar o sistema de controle de constitucionalidade de perfil relativamente concentrado no STF, uma vez que as questões até então não apreciadas no âmbito do controle abstrato de constitucionalidade (ação direta de inconstitucionalidade e ação declaratória de constitucionalidade) poderão ser objeto de exame no âmbito do novo procedimento ${ }^{32}$. (grifo nosso)
\end{abstract}

Nesse aspecto, faz mister lembrar que até o advento da Lei 9.882/99, não era possível o controle abstrato de leis municipais em face da Constituição Federal, sujeito apenas ao controle difuso, conforme entendimento da Corte Suprema.

Então, quando o art. $1^{\circ}$ da Lei $9.882 / 99$ aduz que podem ser objetos da argüição de descumprimento todos os atos do Poder Público, é o mesmo que dizer que podem ser objetos desse novo mecanismo de controle concentrado: os atos normativos municipais, inclusive os anteriores à Constituição, os atos administrativos e de execução praticados pelo Poder Público, desde que descumpram preceitos constitucionais fundamentais.

Imperioso diferenciar ainda os objetos da argüição de descumprimento e da ação direta de inconstitucionalidade. Enquanto que na primeira são apenas os atos do Poder Público que descumpram preceitos fundamentais da Lei Maior, na segunda são quaisquer leis ou atos normativos que contrariem os dispositivos da Constituição Federal. Portanto, o objeto da ação direta é mais amplo do que o da argüição de descumprimento.

Por conseguinte, em razão do objeto da argüição limitar-se apenas aos preceitos constitucionais e não abranger toda e qualquer norma prevista na Constituição Federal, como ocorre nas ações diretas, isso viabiliza que somente chegue ao Supremo Tribunal questões realmente importantes.

Esse fator limitativo da argüição, de uma certa maneira, impede o afogamento da Corte Suprema, afinal, são mais de cinco mil municípios que compõe o sistema federativo brasileiro e permite que leis municipais que contrariem preceitos fundamentais sejam declaradas inconstitucionais através do meio concentrado, colaborando-se, assim, com uma justiça igual para todos e com a segurança do ordenamento jurídico.

\footnotetext{
${ }^{32}$ ADPF 33-PA, Rel. Min. Gilmar Mendes, DJU, 27 out. 2006, p. 31.
} 
A respeito da segurança jurídica é importante lembrar que foi introduzido no ordenamento brasileiro através da Emenda Constitucional 45/2004 ${ }^{33}$ (art. 103-A) a súmula vinculante, em que:

\begin{abstract}
O Supremo Tribunal Federal poderá, de ofício ou por provocação, mediante decisão de dois terços dos seus membros, após reiteradas decisões sobre matéria constitucional, aprovar súmula que, a partir de sua publicação na imprensa oficial, terá efeito vinculante em relação aos demais órgãos do Poder Judiciário e à administração pública direta e indireta, nas esferas federal, estadual e municipal, bem como proceder à sua revisão ou cancelamento, na forma estabelecida em lei.
\end{abstract}

Assim, após haver ampla discussão da matéria nas instâncias inferiores o Supremo pode editar súmula com o objetivo de defender "a validade, a interpretação e a eficácia de normas determinadas, acerca das quais haja controvérsia atual entre órgãos judiciários ou entre esses e a administração pública que acarrete grave insegurança jurídica e relevante multiplicação de processos sobre questão idêntica" (art. 103-A, $\S 1^{\circ}$ ).

A súmula vinculante, como se depreende não se presta para qualquer tema ou questão controvertida e sim para aquelas discussões sobre a constitucionalidade de determinadas normas, discussões relevantes que levam ao Poder Judiciário uma infinidade de processos repetidos, onde se discute a mesma matéria (de direito) e que são objetos de decisões controvertidas, num e noutro sentido, trazendo, como conseqüência, a insegurança jurídica do sistema como um todo ${ }^{34}$.

Sendo assim, para que seja editada uma súmula vinculante exige-se a ampla discussão da matéria. A discussão que começa no primeiro grau de jurisdição, que é revista e rediscutida pelos Tribunais, que chega ao Supremo Tribunal Federal através do Recurso Extraordinário com todos os seus elementos.

E no Recurso Extraordinário foi inserido, também por meio da Emenda Constitucional $\mathrm{n}^{\mathrm{o}}$. 45/2004, como requisito de admissibilidade a demonstração da repercussão geral das questões constitucionais discutidas no caso, ou seja, a manifestação de que a questão posta nos autos é relevante do ponto de vista econômico, político, social ou jurídico e que esta

\footnotetext{
33 Também foi introduzido pela Emenda Constitucional 45/2004, o $\$ 2^{\circ}$ no art. 102 , que aduz que: "As decisões definitivas de mérito, proferidas pelo Supremo Tribunal Federal, nas ações diretas de inconstitucionalidade e nas ações declaratórias de constitucionalidade produzirão eficácia contra todos e efeito vinculante, relativamente aos demais órgãos do Poder Judiciário e à administração pública direta e indireta, nas esferas federal, estadual e municipal".

${ }^{34}$ A título meramente exemplificativo, tem-se a Súmula n. 3 que dispõe que: "é inconstitucional a lei ou ato normativo estadual ou distrital que disponha sobre sistemas de consórcios e sorteios, inclusive bingos e loterias".
} 
discussão ultrapassa os limites dos interesses das partes, atingindo o interesse público, a fim de que o recurso seja admitido pela Corte Suprema. Trata-se de um fator limitativo.

Assim, notadamente com a criação do mecanismo da repercussão geral e da súmula vinculante, o próprio modelo difuso parece estar adquirindo características do modelo abstrato.

Entretanto, é importante salientar que apesar da súmula vinculante representar um novo mecanismo de proteção à segurança jurídica, ela não ofusca a importância da argüição de descumprimento, pois a súmula exige o pré-questionamento nas instâncias inferiores, e isso leva muito tempo, enquanto que na argüição de descumprimento o processamento é direto e caso seja julgada procedente terá efeito erga omnes e vinculante.

Ademais, defende-se para que ocorra o efetivo controle de constitucionalidade, em uma futura reforma do Judiciário, "transformar o Supremo Tribunal em uma Corte Constitucional exclusiva, retirando-lhe a competência para conhecer de matéria que diga a respeito à legislação infraconstitucional, reservando-lhe tão somente a apreciação das questões próprias da jurisdição constitucional" 35 .

Por derradeiro, pode-se concluir que a argüição de descumprimento de preceito fundamental abriu novas portas para o controle abstrato de constitucionalidade de leis municipais e constitui-se mais um mecanismo de defesa à segurança jurídica e a uma justiça mais célere para todos.

\section{Conclusão}

O trabalho apresentou as diversas nuances do controle de constitucionalidades de leis municipais, a começar pela análise da supremacia constitucional até a argüição de descumprimento de preceito fundamental.

Concernente ao controle difuso de leis municipais frente à Constituição Federal, tanto a doutrina como a jurisprudência são pacíficas em afirmar que ele pode e deve ocorrer, sendo que as decisões dos tribunais inferiores poderão ser analisadas novamente pelo Supremo Tribunal Federal, em grau de recurso extraordinário - art. 102, inc. III, $a$ e $c$, da CF.

Todavia, a celeuma ocorre quando se trata de controle concentrado de lei municipal em face da Constituição Federal.

\footnotetext{
${ }^{35}$ ROCHA, Fernando Luiz Ximenes. Controle de constitucionalidade das leis municipais. São Paulo: Editora Athas S.A., 2002, p. 119.
} 
A Constituição de 1998 silencia sobre o controle de constitucionalidade, em tese, de leis e atos normativos municipais perante a Constituição Federal (art. 102, inc. I, $a$, da CF).

Alguns doutrinadores e magistrados sustentaram haver uma autorização implícita, para estender essa competência à norma municipal, ante a condição do Supremo Tribunal Federal de guardião da Carta Magna.

Por sua vez, com base no art. 125, $\S 2^{\circ}$, da Constituição Federal, os Estados-membros acharam que estavam autorizados a disciplinarem a ação direta de inconstitucionalidade tanto diante da Carta Estadual, quanto na Carta Federal, atribuindo ao Tribunal de Justiça local essa competência, em função de os Municípios serem entidades infra-estaduais, o que autorizaria os Estados a prover sobre o sistema de defesa de ambas as esferas constitucionais: estadual e federal.

Contudo, a Corte Suprema não foi solidária com esses posicionamentos e se manifestou contrária ao controle concentrado de leis municipais ante a Constituição Federal, afirmando que se trata de um silêncio proposital do constituinte e que o controle abstrato de leis municipais deve ser realizado, tão-somente, por meio difuso, bem como que os Estados não estariam autorizados a realizar tal controle.

Por outro lado não se pode esquecer a existência de municípios de enorme relevância no cenário nacional, cuja edição de leis inconstitucionais implica a geração de vários processos, com graves prejuízos para as partes e para a segurança jurídica, em virtude da morosidade no julgamento dessas questões pela via do controle difuso, que poderá ocasionar múltiplas e variadas interpretações sobre um mesmo assunto, ensejando, conseqüentemente, o aumento dos recursos perante o Supremo Tribunal Federal.

Paralela a reflexão acima, surge outra questão, se o constituinte federal concedesse ao Supremo Tribunal Federal competência para a análise da constitucionalidade das leis municipais, seguramente a quantidade de Ministros seria insuficiente, em decorrência do elevado número de Municípios existentes no país, o que geraria um caos na Corte Suprema.

Vale lembrar também que com a Emenda n. ${ }^{\circ} 45 / 2004$, o controle de constitucionalidade difuso ganhou um novo reforço, que é, a súmula vinculante, através da qual, o Supremo, após reiteradas decisões sobre matéria constitucional, pode editar súmula com o objetivo de defender a validade, a interpretação e a eficácia de normas determinadas, acerca das quais haja controvérsia atual entre órgãos judiciários ou entre esses e a administração pública que acarrete grave insegurança jurídica e relevante multiplicação de processos sobre questão idêntica. 
Então, pode-se afirmar que apesar do controle abstrato de constitucionalidade de legislação municipal ser importante para o ordenamento jurídico como um todo, para a Corte Suprema ele não é conveniente, o que deixa claro que o silêncio do legislador constituinte em não disciplinar o controle concentrado de leis municipais configurou-se na expressa vontade de limitar o controle de constitucionalidade concentrado ao modelo estabelecido na Lei Maior.

No entanto, a Lei 9882/99 veio suprir a lacuna deixada pelo constituinte no art. 102, inc. I, $a$, da CF, disciplinando, expressamente, a possibilidade de controle de constitucionalidade de lei municipal perante a Constituição através da argüição de descumprimento de preceito fundamental.

Assim, ao contrário do imaginado por alguns, não será necessário que a Corte Suprema julgue as questões constitucionais relativas ao direito de todos os municípios. Nos casos relevantes, bastará que decida uma questão-padrão com força vinculante.

No entanto, é importante salientar que apesar da súmula vinculante representar um novo mecanismo de proteção à segurança jurídica, ela não ofusca a relevância da argüição de descumprimento, pois a súmula exige o pré-questionamento nas instâncias inferiores, e isso leva muito tempo, enquanto que na argüição de descumprimento o processamento é direto e caso seja julgada procedente terá efeito erga omnes e vinculante.

Por derradeiro, pode-se afirmar, então, que a argüição de descumprimento de preceito fundamental abriu novas portas para o controle abstrato de constitucionalidade de leis municipais e constitui-se mais um mecanismo de defesa à segurança jurídica e a uma justiça mais célere para todos.

E por fim, em resposta às indagações inicialmente propostas neste trabalho, pode-se concluir que os posicionamentos contrários à fiscalização das leis municipais perante a Constituição Federal não devem vigorar, haja vista a importância e abrangência que determinadas leis municipais acarretam aos grandes municípios brasileiros e levando-se em conta a falta de segurança que inúmeras demandas judiciais questionando a constitucionalidade poderiam causar ao ordenamento jurídico. Acredita-se que o controle concentrado de constitucionalidade de lei municipal deve ocorrer sim, contudo, através das prerrogativas da argüição de descumprimento de preceito fundamental. 


\section{REFERÊNCIAS BIBLIOGRÁFICAS}

ARAUJO, Luiz Alberto David e outro. Curso de direito constitucional, 10 a ed., São Paulo: Saraiva, 2006.

BASTOS, Celso Ribeiro. As modernas formas de interpretação constitucional. Jus Navegandi. Teresina, ano 3, n. 27, dez. 1998. Disponível em: <http://jus2.uol.com.br/doutrina/texto.asp?id=89>. Acesso em: 05 jun. 2010.

BITTENCOURT, C. A. Lúcio. O controle jurisdicional da constitucionalidade das leis. Atualizado por José Aguiar Dias. 2a ed. Brasília: Ministério da Justiça, 1997.

BONAVIDES, Paulo. Curso de direito constitucional. 9. ed. São Paulo: Malheiros, 2000.

CLÈVE, Clemerson Merlin. A fiscalização abstrata de constitucionalidade no direito brasileiro. $2^{\mathrm{a}}$ ed. São Paulo, RT, 2000.

FERRARI, Regina Maria Macedo Nery. Controle de Constitucionalidade das Leis municipais. 3. ed. São Paulo: Editora Revista dos Tribunais, 2003.

Elementos de direito municipal. São Paulo: Editora Revista dos Tribunais, 1993.

FERRAZ, Sérgio. A declaração de inconstitucionalidade no Supremo Tribunal federal. Ajuris 61.

FERREIRA, Pinto. Princípios gerais do direito constitucional moderno. 5. ed. São Paulo: Revista dos Tribunais, 1971. V. 1.

FLORES, Patrícia Teixeira de Rezende. Aspectos processuais da ação direta de inconstitucionalidade de lei municipal. São Paulo: Editora Revista dos Tribunais, 2002.

HÄBERLE, Peter. Tradução por MENDES, Gilmar Ferreira. Hermenêutica constitucional - a sociedade aberta dos intérpretes da constituição: contribuição para interpretação pluralista e procedimental da constituição. Porto Alegre: Metrópole Indústria Gráfica, 1997.

HESSE, Korand. Tradução por MENDES, Gilmar Ferreira. Die normative kraft der verfassung - A força normativa da constituição. Porto Alegre: Sérgio Antônio Fabris Editor, 1991.

HORTA, Raul Machado. Direito constitucional. 4. ed. rev. e atual. Belo Horizonte: Del Rey, 2003.

MANDELLI JUNIOR, Roberto Mendes. Argüição de descumprimento de preceito fundamental: instrumento de proteção dos direitos fundamentais e da Constituição. São Paulo: Editora Revista dos Tribunais, 2003.

MAXIMILIANO, Carlos. Hermenêutica e aplicação do direito. $9^{\mathrm{a}}$ ed. Rio de Janeiro: Forense, 1981. 
MENDES, Gilmar Ferreira. Controle de constitucionalidade: aspectos jurídicos e políticos. São Paulo: Saraiva, 1990.

Direitos fundamentais e controle de constitucionalidade. 3. ed. São Paulo: Editora Saraiva, 2004.

MORAES, Alexandre. Direito Constitucional. 13ª ed. São Paulo: Atlas, 2003.

PALU, Oswaldo Luiz. Controle de constitucionalidade: conceitos, sistemas e efeitos. $2^{\mathrm{a}}$ ed. São Paulo: Revista dos Tribunais, 2001.

ROCHA, Fernando Luiz Ximenes. Controle de constitucionalidade das leis municipais. São Paulo: Editora Athas S.A., 2002.

SILVA, De Plácido e. Vocabulário jurídico. 3. ed., v. I, São Paulo: Forense, 1993.

SILVA, José Afonso. Curso de direito constitucional positivo. $24^{a}$ ed. São Paulo: Editora Malheiros, 2005.

STRECK, Lênio Luiz. Jurisdição constitucional e hermenêutica: uma nova crítica do direito. $2^{\mathrm{a}}$ ed. Rio de Janeiro: Forense, 2004.

TAVARES, André Ramos e ROTHENBURG, Walter Claudius - organizadores. Aspectos atuais do controle de constitucionalidade no Brasil: recurso extraordinário e argüição de descumprimento de preceito fundamental. Rio de Janeiro: Forense, 2003. 